\title{
Fertilizer and intercropped legumes as nitrogen source for Jerusalem artichoke (Helianthus tuberosus L.) tops for bioenergy
}

\author{
Kenedy E. Epie ${ }^{1,2}$, Arja Santanen ${ }^{1}$, Pirjo S.A. Mäkelä ${ }^{1}$ and Frederick L. Stoddard ${ }^{1}$ \\ ${ }^{1}$ Department of Agricultural Sciences, P.O. Box 27, 00014 University of Helsinki, Finland \\ ${ }^{2}$ Present address: Montana State University, Western Triangle Agricultural Research Center (WTARC), USA \\ e-mail: etone.kenedy@montana.edu
}

\begin{abstract}
Jerusalem artichoke (Helianthus tuberosus L.) produces substantial shoots not used as food. To test its potential as a sustainable bioenergy crop, we studied the effects of synthetic fertilizer and intercropped legumes as nitrogen (N) sources on the growth, aboveground biomass dry matter yield and energy qualities of this crop. Plant height, leaf area index (LAI), SPAD-value, biomass yield, ash content and mineral element composition were determined. Mean aboveground biomass yields were not significantly affected by $\mathrm{N}$ source (legume intercrops and synthetic fertilizer) and ranged from 13 to $17 \mathrm{t} \mathrm{ha}^{-1}$. Remarkably, plants given no fertilizer yielded equally to plants given $90 \mathrm{~N}$ $\mathrm{kg} \mathrm{ha}^{-1}$. These results confirm that Jerusalem artichoke, compared to other energy crops, have less need for $\mathrm{N}$ and can potentially be sustained by $\mathrm{N}$ fixing legumes in an intercropped system. This could reduce or eliminate production and environmental cost in cultivation of biomass feedstock for energy use.
\end{abstract}

Key words: Helianthus tuberosus, synthetic nitrogen fertilizer, intercropping, legumes, biomass, mineral element composition

\section{Introduction}

Jerusalem artichoke (Helianthus tuberosus L.) is an herbaceous perennial plant, related to sunflower (Helianthus annuus L.), and has long been grown for its edible tubers, as livestock feed and as an ornamental (Ben Chekroun 1990, Rodrigues et al. 2007, Ma et al. 2011). The main industrial use of the crop is centred on its fructan-rich tubers hydrolysed to produce fructose (Monti et al. 2005). A recent review by Johansson et al. (2015) detailed the potential of Jerusalem artichoke as a source of protein and a biorefinery crop. The plant grows rapidly, requires minimal pesticides, fertilizer and water, tolerates marginal land and produces plentiful biomass (Long et al. 2014, Yang et al. 2015). Although often managed as an annual, the crop is perennial, and there is potential to manage it in that way in order to maximize the production from a single set of establishment costs. It is highly frost-tolerant (Negro et al. 2006), being native to eastern North America as far north as the province of Quebec.

The crop has bioenergy potential. This would require managing the crop as a perennial and annual nutrient replenishment. Efforts to lower energy input by reducing fertilizer use in bioenergy crop production could improve sustainability. Jerusalem artichoke is a good candidate for this purpose because it is less responsive to $\mathrm{N}$ fertilization than most energy crops (Slimestad et al. 2010).

The above-ground biomass of Jerusalem artichoke can be used to produce biogas and bioethanol (Cervigni 1990, Tuck et al. 2006) with heating value of $15.5 \mathrm{MJ} \mathrm{kg}^{-1}$ (Tencl and Sladky 2001), and could be burnt for combined heat and power production (CHP) or fermented after acid hydrolysis to break down the ligno-cellulosic biomass to fermentable carbohydrate for transportation biofuel (Philp et al. 2013). Baldini (2004) recorded above-ground biomass of $25 \mathrm{t} \mathrm{ha}^{-1}$ dry matter. Mays et al. (1990) reported a biomass yield of $30.7 \mathrm{t} \mathrm{ha}^{-1}$ when $56 \mathrm{~N} \mathrm{~kg} \mathrm{ha}^{-1}$ fertilizer was applied.Legumes biologically fix $\mathrm{N}$ and their inclusion into cropping systems, particularly as intercrops, can reduce energy use by reducing the need for $\mathrm{N}$ fertilizer of the co-crop (Jensen and Hauggaard-Nielsen 2003).

Partly due to its potential as a bioenergy crop, the cultivation of Jerusalem artichoke as a specialty crop is increasing (Yang et al. 2015). Information on field performance at high latitudes is scarce and there are few studies on this crop's response to mineral nutrition, especially synthetic $\mathrm{N}$ fertilizer. There is even less information on the potential responses of Jerusalem artichoke to intercropping with legumes. According to Curt et al. (2006), studies on Jerusalem artichoke for bioenergy use have not been exhaustive and this is still true. The objective of the study was to assess the effects of synthetic fertilizer and legume intercrops on growth, aboveground biomass yield, mineral element composition and energy quality of Jerusalem artichoke. 


\section{Materials and Methods \\ Experimental site}

Field studies were conducted in 2009 to 2011 at the Viikki Research Farm, University of Helsinki, Finland $\left(60^{\circ} 13^{\prime}\right.$

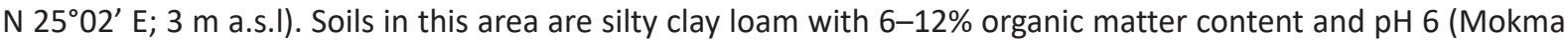
et al. 2000). The weather data (Table 1) was recorded each year at the Finnish Meteorological Institute (FMI), Kaisaniemi station, $9 \mathrm{~km}$ from the experimental site. Mean temperatures in 2009 and 2011 were higher than longterm average, whereas 2010 was cooler than the long-term average. The wettest year was 2011 with a total precipitation of $748 \mathrm{~mm}$.

Table 1. Mean air temperature $\left({ }^{\circ} \mathrm{C}\right)$ and total monthly precipitation (mm) in Helsinki from 2009 to 2011 , and the long-term averages (1981-2010) (Finnish Meteorological Institute)

\begin{tabular}{|c|c|c|c|c|c|c|c|c|}
\hline \multirow[t]{2}{*}{ Month } & \multicolumn{3}{|c|}{ Mean air temperature $\left({ }^{\circ} \mathrm{C}\right)$} & \multirow[b]{2}{*}{2011} & \multicolumn{4}{|c|}{ Total monthly precipitation (mm) } \\
\hline & 1981-2010 & 2009 & 2010 & & 1981-2010 & 2009 & 2010 & 2011 \\
\hline January & -3.9 & -2.8 & -10.4 & -4.4 & 52 & 33 & 30 & 70 \\
\hline February & -4.7 & -3.6 & -8.1 & -9.9 & 36 & 20 & 45 & 24 \\
\hline March & -1.3 & -0.9 & -1.8 & -1.0 & 38 & 34 & 54 & 15 \\
\hline April & 3.9 & 4.5 & 4.6 & 5.6 & 32 & 7 & 42 & 29 \\
\hline May & 10.2 & 11 & 11.5 & 9.9 & 37 & 45 & 59 & 27 \\
\hline June & 17.8 & 14.1 & 14.6 & 16.7 & 63 & 75 & 33 & 49 \\
\hline July & 16.3 & 17.2 & 21.7 & 20.6 & 80 & 131 & 49 & 56 \\
\hline August & 15.8 & 16.7 & 18.1 & 17.5 & 79 & 49 & 97 & 173 \\
\hline September & 11.5 & 13.5 & 12.2 & 13.6 & 56 & 40 & 50 & 88 \\
\hline October & 6.6 & 4.2 & 6.0 & 8.5 & 76 & 90 & 29 & 69 \\
\hline November & 1.6 & 3.6 & -0.5 & 5.3 & 70 & 86 & 89 & 27 \\
\hline December & -2.0 & -3.6 & -7.5 & 3.4 & 58 & 51 & 87 & 121 \\
\hline Average/Total & 5.9 & 6.2 & 5.1 & 7.2 & 677 & 661 & 664 & 748 \\
\hline
\end{tabular}

\section{Establishment of intercropping experiment}

In May 2009, seed tubers of Jerusalem artichoke cultivar "French white" were manually planted $10 \mathrm{~cm}$ deep into $12 \mathrm{~m}^{2}$ plots, $30 \mathrm{~cm}$ within and $60 \mathrm{~cm}$ between rows. Five treatments were studied: sole-cropped Jerusalem artichoke fertilized in the first year shortly after planting and in the second year in May with $60 \mathrm{~N} \mathrm{~kg} \mathrm{ha}^{-1}$ fertilizer (EY Lannoite NPK 16-7-13, Cemagro Oy, Lohja, Finland) and four pre-inoculated legumes each sown into the Jerusalem artichoke plots. The legumes were goat's rue (Galega orientalis L.), red clover (Trifolium pratense L.), sweet clover (Melilotus alba Medik.) and vetch (Vicia sativa L.) sown at 23, 7, 20 and $49 \mathrm{~kg} \mathrm{ha}^{-1}$, respectively. Goat's rue was inoculated with Rhizobium galegae, red clover with $R$. leguminosarum biovar trifolii, sweet clover with Sinorhizobium meliloti, and vetch with R. leguminosarum biovar viciae. No fertilizer was applied in legume plots. Weeds were manually removed when necessary. The treatments were arranged in a randomized complete block design with four replicates.

\section{Establishment of $\mathrm{N}$ fertilizer experiments}

In May 2010 and 2011, seed tubers of equal sizes were manually planted in $1 \mathrm{~m} \times 3 \mathrm{~m}$ plots with the same plant spacing as in 2009. Prior to planting, 0, 30, 60 and $90 \mathrm{~N} \mathrm{~kg} \mathrm{ha}^{-1}$ (EY Lannoite NPK 16-7-13, Cemagro Oy, Lohja, Finland) was applied and harrowed in the soil. The experiment was arranged in a randomized complete block design with four replications. Weeds were manually removed when necessary.

\section{Growth measurements}

At the onset of flowering during each growing season, plant height $(\mathrm{cm})$ from soil surface to the highest point of the canopy was measured. Leaf Area Index (LAI) was measured between 0900 and 1100 during the day by a Sun- 
Scan Canopy Analysis System equipped with a BF3 sunshine sensor (SS1-UM-2.0, Delta-T Devices Ltd, Cambridge, UK). The SPAD-values of fully expanded young leaves were measured (SPAD-502 Chlorophyll meter, Minolta, Japan).

At the end of September, above-ground biomass from $1 \mathrm{~m}^{2}$ area was manually harvested from each plot. In the legume intercropped trial, the rest of the plots were cleared to allow regrowth in the following growing season. The tubers were harvested with a potato harvester in each year, and fragments missed by the harvester reestablished the plots in the following spring. The harvested samples were dried at $70{ }^{\circ} \mathrm{C}$ for 3 days and weighed. Dried samples were crushed and ground ( $0.5 \mathrm{~mm}$ sieve, ZM 200 centrifugal mill, Retsch GmbH, Haan, Germany) and and stored at room temperature in sealed plastic bags until further analysis.

\section{Analysis of mineral elements and energy}

Ground samples were subsequently used to determine ash content, energy value and mineral element composition of the biomass. Ash content was determined by burning one gram of dried ground samples in a muffle furnace (LV 15/11/P320, Nabertherm GmbH, Germany) for $12 \mathrm{~h}$ at $575^{\circ} \mathrm{C}$, cooled in a desiccator and weighed. A bomb calorimeter (Parr 1241EA, Parr Instrument Co., Moline, IL, USA) was used to determine the energy value as described by Seleiman et al. (2013). Total C and N concentrations were determined using a Vario Max CN (Elementar Analysensysteme $\mathrm{GmbH}$, Germany). The concentration of chloride (Cl) was analysed according to Mäkelä et al. (1998) using a chloride analyser (Model 926, Sherwood Scientific Ltd., Cambridge, U.K.). Concentrations of calcium (Ca), magnesium (Mg), potassium (K) and sulphur (S) were determined with an Inductively Coupled Plasma Optical Emission Spectrometer (iCAP 6200, Thermo Fisher Scientific, Cambridge, UK) after microwave-assisted digestion with nitric acid as previously described by Epie et al. (2014).

\section{Statistical Analysis}

Data were subjected to analysis of variance (ANOVA) using SPSS version 24 statistical software (IBM, Armonk, NY, USA). Levene's test of homogeneity of variance of two-year data for all variables was not significant, so a combined ANOVA was performed (Gomez and Gomez 1984). Tukey's b test was used to separate means at probability level of $5 \%$.

\section{Results}

Legumes in the intercrops did not have a significant effect on total above-ground biomass and energy yields of Jerusalem artichoke (Table 2). Above-ground biomass yields ranged from 13 to $17 \mathrm{t} \mathrm{ha}{ }^{-1}$. Plants fertilized with synthetic $\mathrm{N}$ grew taller than those intercropped with legumes although significantly so with only vetch $(p<0.05)$. Goat's rue and sweet clover intercrops or fertilized Jerusalem artichoke had significantly $(p<0.05)$ higher LAI values than the other two treatments.

Table 2. Leaf area index (LAI), height, aboveground biomass and energy yield of Jerusalem artichoke treated with N fertilizer or intercropped with legumes during two growing seasons (2009 and 2010) in Helsinki, Finland.

\begin{tabular}{lcccc} 
Treatment & Height $(\mathrm{cm})$ & LAl & Biomass $\left(\mathrm{t} \mathrm{ha}^{-1}\right)$ & Energy yield (GJ ha $\left.{ }^{-1}\right)$ \\
\hline $60 \mathrm{~N} \mathrm{~kg} \mathrm{ha}^{-1}$ & $176 \mathrm{~b}$ & $9.4 \mathrm{~b}$ & 17 & 268 \\
Goat's rue & $164 \mathrm{ab}$ & $9.5 \mathrm{~b}$ & 14 & 223 \\
Red clover & $161 \mathrm{ab}$ & $7.4 \mathrm{a}$ & 15 & 239 \\
Vetch & $152 \mathrm{a}$ & $7.0 \mathrm{a}$ & 13 & 213 \\
Sweet clover & $163 \mathrm{ab}$ & $9.5 \mathrm{~b}$ & 14 & 217 \\
$p$-value & $* *$ & $* * *$ & $\mathrm{~ns}$ & $\mathrm{~ns}$ \\
\hline
\end{tabular}

Means in the same column followed by the same letter(s) are not different at $p \leq 0.05$ probability levels by Tukey b; ns=not significant; $* *, * * * p \leq 0.01, p \leq 0.001$, respectively

$\mathrm{N}$ fertilizer and intercropping with legumes did not significantly influence the ash, $\mathrm{Cl}, \mathrm{Ca}, \mathrm{Mg}$ concentrations and $\mathrm{C}: \mathrm{N}$ ratio of Jerusalem artichoke (Table 3). Mean ash content was $7.1 \%$. K) concentration was significantly higher in the $\mathrm{N}$-fertilized treatment than in the goat's rue and vetch treatments, and S concentration was higher in the synthetic fertilizer treatment than in three of the legume treatments. The C:N ratio averaged 68. 
Table 3. Ash content and mineral element composition of Jerusalem artichoke treated with $\mathrm{N}$ fertilizer or intercropped with legumes during two growing seasons (2009 and 2010) in Helsinki, Finland. Data shown are means, $\mathrm{n}=8$.

\begin{tabular}{lccccccc}
\hline Treatment & Ash (\%) & $\mathrm{Cl}\left(\mathrm{g} \mathrm{kg}^{-1}\right)$ & $\mathrm{Ca}\left(\mathrm{g} \mathrm{kg}^{-1}\right)$ & $\mathrm{K}\left(\mathrm{g} \mathrm{kg}^{-1}\right)$ & $\mathrm{Mg}\left(\mathrm{g} \mathrm{kg}^{-1}\right)$ & $\mathrm{S}\left(\mathrm{g} \mathrm{kg}^{-1}\right)$ & $\mathrm{C}: \mathrm{N} \mathrm{ratio}$ \\
\hline $60 \mathrm{~N} \mathrm{~kg} \mathrm{ha}^{-1}$ & 7.1 & 1.9 & 12.2 & $27.8 \mathrm{~b}$ & 1.8 & $1.4 \mathrm{~b}$ & 58 \\
Goat's rue & 6.6 & 1.7 & 9.5 & $18.5 \mathrm{a}$ & 1.3 & $0.7 \mathrm{a}$ & 75 \\
Red clover & 7.4 & 2.0 & 11.7 & $22.2 \mathrm{ab}$ & 1.7 & $0.9 \mathrm{ab}$ & 66 \\
Vetch & 6.8 & 1.8 & 10.5 & $19.6 \mathrm{a}$ & 1.5 & $0.8 \mathrm{a}$ & 68 \\
Sweet clover & 7.4 & 2.0 & 11.8 & $22.2 \mathrm{ab}$ & 1.7 & $0.7 \mathrm{a}$ & 75 \\
$p$-value & $\mathrm{ns}$ & $\mathrm{ns}$ & $\mathrm{ns}$ & $* * *$ & $\mathrm{~ns}$ & $*$ & $\mathrm{~ns}$ \\
\hline
\end{tabular}

Means in the same column followed by the same letter(s) are not different at $p \leq 0.05$ probability levels by Tukey b. ns=not significant; $*, * * *$ $p \leq 0.05, p \leq 0.001$, respectively

In the second year of the experiment, and also in the year following the experiment, the Jerusalem artichoke plots re-established naturally from tuber fragments left after machine harvesting. Goat's rue re-established in the second year, but the other three legume co-crops did not (data not shown).

In the second study, different rates of synthetic $\mathrm{N}$ fertilizer did not have significant effects on height, SPAD-value, LAI, biomass and energy yields, ash content and mineral element composition of above-ground biomass of the Jerusalem artichoke plants (Table 4 and 5). Shoot biomass yield averaged $11.6 \mathrm{t} \mathrm{ha}^{-1}$ and ash content averaged $10.6 \%$.

Table 4. Height, SPAD-value, leaf area index (LAI), above-ground biomass and energy yield of Jerusalem artichoke grown at four N fertilizer rates during two growing seasons (2010 and 2011) in Helsinki, Finland.

\begin{tabular}{cccccc}
\hline $\begin{array}{c}\mathrm{N} \text { fertilizer treatment } \\
\left(\mathrm{kg} \mathrm{ha}^{-1}\right)\end{array}$ & Height $(\mathrm{cm})$ & SPAD-value & LAl & Biomass yield $\left(\mathrm{t} \mathrm{ha}^{-1}\right)$ & $\begin{array}{c}\text { Energy yield } \\
\left(\mathrm{GJ} \mathrm{ha}^{-1}\right)\end{array}$ \\
\hline 0 & 160 & 34.8 & 5.8 & 11.1 & 190 \\
30 & 161 & 34.9 & 6.3 & 11.5 & 182 \\
60 & 155 & 34.8 & 5.8 & 12.0 & 190 \\
90 & 159 & 35.7 & 6.1 & 11.7 & 186 \\
$p$-value & $\mathrm{ns}$ & $\mathrm{ns}$ & $\mathrm{ns}$ & $\mathrm{ns}$ & $\mathrm{ns}$ \\
\hline
\end{tabular}

ns=not significant

Table 5. Ash content and mineral element composition of Jerusalem artichoke grown at four $\mathrm{N}$ fertilizer rates rates during two growing seasons (2010 and 2011) in Helsinki, Finland. Data shown are means, $\mathrm{n}=8$.

\begin{tabular}{|c|c|c|c|c|c|c|c|}
\hline $\begin{array}{l}\mathrm{N} \text { fertilizer treatment } \\
\qquad\left(\mathrm{kg} \mathrm{ha}^{-1}\right)\end{array}$ & Ash (\%) & $\mathrm{Cl}\left(\mathrm{g} \mathrm{kg}^{-1}\right)$ & $\mathrm{Ca}\left(\mathrm{g} \mathrm{kg}^{-1}\right)$ & $\mathrm{K}\left(\mathrm{g} \mathrm{kg}^{-1}\right)$ & $\mathrm{Mg}\left(\mathrm{g} \mathrm{kg}^{-1}\right)$ & $\mathrm{S}\left(\mathrm{g} \mathrm{kg}^{-1}\right)$ & $\mathrm{C}: \mathrm{N}$ ratio \\
\hline 0 & 11.1 & 2.4 & 8.0 & 23.6 & 1.2 & 1.3 & 30.2 \\
\hline 30 & 10.6 & 2.2 & 7.8 & 24.3 & 1.1 & 1.4 & 29.6 \\
\hline 60 & 10.3 & 2.1 & 8.0 & 25.2 & 1.2 & 1.5 & 30.5 \\
\hline 90 & 11.3 & 2.4 & 7.7 & 23.5 & 1.1 & 1.4 & 31.3 \\
\hline$p$-value & ns & ns & ns & ns & ns & ns & ns \\
\hline
\end{tabular}

ns=not significant

\section{Discussion}

According to the results Jerusalem artichoke tolerated both low rates of $\mathrm{N}$ fertilization and the presence of cocrops, and that key aspects of composition of the above-ground matter and yield were relatively unchanged by the treatments studied.

The low $\mathrm{N}$ fertilizer requirement of Jerusalem artichoke shown in this study has been reported in earlier studies (Duke 1983, Slimestad et al. 2010). SPAD-value, which is often used as an indicator of N deficit in tuberous crops (Rodrigues et al. 2005), was consistent across treatments in this study, as previously shown in Spain by Rodrigues et al. (2007). Elsewhere, high $\mathrm{N}$ fertilizer rates were associated with increased tuber yield in Spain (Rodrigues et 
al. 2007) and above-ground biomass yield in France (Barloy 1988), but this was not the case in this study. Jerusalem artichoke has shown a strong ability to extract nutrients from soils (Cors and Falisse 1980) and it may be that its root exudates are effective at promoting the breakdown of soil organic matter, freeing mineral $\mathrm{N}$ that is then taken up. The literature on root exudates from Helianthus species is surprisingly scarce (Bowsher et al. 2016). Soil organic $\mathrm{N}$ concentrations are high on the Viikki farm, following five centuries of cattle farming (Tammeorg et al. 2014). Although, there was no response to $\mathrm{N}$ fertilizer in this study, the results tend to indicate $60 \mathrm{~N} \mathrm{~kg} \mathrm{ha}^{-1}$, where soil $\mathrm{N}$ content is low, in line with previous recommendations of a maximum application for Jerusalem artichoke tuber yields (Schittenhelm 1999). Increasing N fertilizer rates also showed little effect on mineral element composition of the Jerusalem artichoke tops.

In both experiments, Jerusalem artichoke crop yields were highly variable between replicates as well as between treatments, in line with previous studies (Denoroy 1996). Furthermore, there was a large difference in yields between the experiments, although they were only about $200 \mathrm{~m}$ apart and grew in overlapping years as the legume experiment was conducted in 2009 and 2010 while the fertilizer experiment was conducted in 2010 and 2011. The year 2009 had more precipitation in June and July than the other two years. Jerusalem artichoke is considered to be sensitive to soil moisture (Mezencev 1985), and high precipitation was associated with the greater plant height and higher LAI in the intercropped experiment than in the fertilizer experiment. Barloy and Fernandez (1991) reported a five-fold difference in tuber yields of Jerusalem artichoke, depending on growing conditions. Maybe harvesting the above-ground dry matter late in October when high shoot biomass yields are obtained in Jerusalem artichoke (Gunnarson et al. 2014) could have mitigated the yield differences in this study.

The legume intercrops were poorly durable in the dense shade (high LAI) of the Jerusalem artichoke. LAI values in this study were in line with those reported for normal growing conditions (Hay and Offer 1992). The vetch chosen was an annual, but there was no evidence of re-establishment from self-sown seed. The soil disturbance during harvesting with the mechanical potato harvester would have resulted in further weakening of the co-crops. The scarcity of related literature suggests that the high LAI of this crop and the annual disturbance of soil during harvest together preclude long-term intercropping of Jerusalem artichoke.

When this work started, sustainable sources of $\mathrm{N}$ for energy crops were sought in order to minimize the fossil fuel usage and greenhouse gas release attendant on fertilizer synthesis (Stoddard 2007), and biological $\mathrm{N}$ fixation by legumes was seen as appropriate. Since that time, it has become clear that $\mathrm{N}$ for bioenergy crops can be obtained from biogas plant digestate and other recycled sources.

The experimental treatments had little significant effect on the mineral element composition of the above-ground biomass of the Jerusalem artichoke. There was a difference between the experiments, with the N-fertilized experiment showing higher ash content than the intercropping experiment. Part of this difference may be due to the provision of $\mathrm{P}, \mathrm{K}$ and $\mathrm{S}$ and trace elements in the fertilizer used in the study. Rodrigues et al. (2007) found that mineral element composition of leaves of Jerusalem artichoke was not affected by cropping practices including $\mathrm{N}$ fertilizer application. Concentrations of ash-forming elements in the intercropping Jerusalem experiment were similar to values of some perennial grasses grown for bioenergy (Epie et al. 2014). Low ash content is desirable for biomass intended for burning in combined heat and power plants. The high C:N ratio obtained at harvest is associated with high calorific values in combustion systems (Obernberger and Thek 2004), also indicative of high potential methane yield in a digester or bioethanol yield.

Jerusalem artichoke produced equally good yields with little or no synthetic fertilizer, confirming its low nutrient requirement, so it could serve as a good source of biomass feedstock for energy production. When intercropped with legumes, artichoke grew well and yielded equally well as with fertilizer. The lack of significant differences between intercropped and fertilized plants suggest that legumes can potentially sustain Jerusalem artichoke during the establishment year. Further studies with no fertilizer and no legume control treatments are recommended before definite conclusions can be made.

\section{Acknowledgments}

We express our sincere gratitude to the staff of the Department of Agricultural Sciences, University of Helsinki, most especially Markku Tykkyläinen for technical assistance. This work was supported by the Academy of Finland grant 1124435, 'Carbon-sequestering species mixtures for sustainable energy cropping', and Doctoral Programme in Sustainable Use of Renewable Natural Resources, University of Helsinki. 


\section{References}

Baldini, M., Danuso, F., Turi, M. \& Vannozzi, G.P. 2004. Evaluation of new clones of Jerusalem artichoke (Helianthus tuberosus L.) for inulin and sugar yield from stalks and tubers. Industrial Crops and Products 19: 25-40. https://doi.org/10.1016/S09266690(03)00078-5

Barloy, J. 1988. Techniques of cultivation of the Jerusalem artichoke. In: Grassi G. \& Gosse, G. (eds). Topinambour (Jerusalem artichoke). Proceedings of EEC Workshop on Jerusalem Artichoke, Madrid, 30 September-1 October 1987. EEC report EUR 11855, Office for Official Publications of the European Communities, Luxembourg.

Barloy, J. \& Fernandez, J. 1991. Synthesis on Jerusalem artichoke projects. In: Gosse, G. \& Grassi, G. (eds). Topinambour (Jerusalem artichoke), Proceedings of 2nd ECC Workshop on Jerusalem Artichoke, Rennes 6-8 December 1988. ECC report EUR, Office for Official Publications of the European Communities, Luxembourg.

Ben Chekroun, M. 1990. Evolution hivernale des glucides (inuline et polyfructosanes) dans les tubercules de topinambour (Helianthus tuberosus L) et la racine de chicorée (Cichorium intybus L.). Thèse, Université de Limoges, 1990. 146 p. (in French).

Bowsher, A.W., Ali, R., Harding, S.A., Tsai, C.-J. \& Donovan, L.A. 2016. Evolutionary divergences in root exudate composition among ecologically-contrasting Helianthus species. PLoS ONE. 11(1). https://doi.org/10.1371/journal.pone.0148280

Cervigni, T. 1990. Topinambur. L'Italia Agricola 3: 106-110. (in Italian).

Cors, F. \& Falisse, A. 1980. Etude des perspectives de culture du topinambour en region limoneuse Belge. Center de Recherche Phytotechnique sur les Proteagineux et Oleagineux, Faculte de Science, Gembloux. 72 p. (in French).

Curt, M.D., Aguado, P., Sanz, M., Sànchez, G. \& Fernàndez, J. 2006. Clone precocity and the use of Helianthus tuberosus L. stems for bioethanol. Industrial Crops and Products 24: 314-320. https://doi.org/10.1016/j.indcrop.2006.06.003

Denoroy, P. 1996. The crop physiology of Helianthus tuberosus L.: A model orientated view. Biomass and Bioenergy 11: 11-32. https://doi.org/10.1016/0961-9534(96)00006-2

Duke, J.A. 1983. Handbook of Energy Crops. https://hort.purdue.edu/newcrop/duke_energy/dukeindex.html

Epie, K.E., Virtanen, S., Santanen, A., Simojoki, A. \& Stoddard, F.L. 2014. The effects of a permanently elevated water table in an acid sulphate soil on reed canary grass for combustion. Plant and Soil 375: 149-158. https://doi.org/10.1007/s11104-013-1925-4 Gomez, K.A. \& Gomez, A.A. 1984. Statistical Procedures for Agricultural Research. New York: John Wiley and Sons. 680 p.

Gunnarsson, I.B., Svensson, S.E., Johansson, E., Karakashev, D. \& Angelidaki, I. 2014. Potential of Jerusalem artichoke (Helianthus tuberosus L.) as a biorefinery crop. Industrial Crops and Products 56: 231-240. https://doi.org/10.1016/j.indcrop.2014.03.010

Hay, R.K.M. \& Offer, N.W. 1992. Helianthus tuberosus as an alternative forage crop for cool maritime regions- a preliminary study of the yield and nutritional quality of shoot tissues from perennial stands. Journal of the Science of Food and Agriculture 60: 213-221. https://doi.org/10.1002/jsfa.2740600209

Jensen, E.S. \& Hauggaard-Nielsen, H. 2003. How can increased use of biological $\mathrm{N}_{2}$ fixation in agriculture benefit the environment? Plant and Soil 252: 177-186. https://doi.org/10.1023/A:1024189029226

Johansson, E., Prade T., Angelidaki, I., Svensson, S.E., Newson, W.R., Gunnarsson, I.B. \& Hovmalm, H.P. 2015. Economically viable components from Jerusalem Artichoke (Helianthus tuberosus L.) in a Biorefinery concept. International Journal of Molecular Science 16: 8997-9016. https://doi.org/10.3390/ijms16048997

Long, X.H., Zhao, J., Liu, Z.P., Rengel, Z., Liu, L., Shao, H.B. \& Tao, Y. 2014. Applying geostatistics to determine the soil quality improvement by Jerusalem artichoke in coastal saline zone. Ecological Engineering 70: 319-326. https://doi.org/10.1016/j.ecoleng.2014.06.024

Ma, X.Y., Zhang, L.H., Shao, H.B., Xu, G., Zhang, F., Ni, F.T. \& Brestic, M. 2011. Jerusalem artichoke (Helianthus tuberosus), a medicinal salt-resistant plant has high adaptability and multiple-use values. Journal of Medicinal Plants Research 5: 1272-1279.

Mäkelä, P., Munns, R., Colmer, T.D., Condon, A.G. \& Peltonen-Sainio, P. 1998. Effect of foliar applications of glycinebetaine on stomatal conductance, abscisic acid and solute concentrations in leaves of salt- or drought-stressed tomato. Australian Journal of Plant Physiology 25: 655-663. https://doi.org/10.1071/PP98024

Mays, D.A., Buchanan, W., Bradford, N. \& Giordano, P.M. 1990. Fuel production potential of several agricultural crops. In: Janick, J. and Simon, J.E. (eds). Advances in New Crops. Portland, OR: Timber Press. p. 260-263.

Mezencev, N. 1985. Premiers resultats des essais AZF/AFME sur topinambours en Midi-Pyrenees. AZF/CdF Chimie, Toulouse. 26 p. (in French).

Mokma, D.L., Yli-Halla, M. \& Hartikainen, H. 2000. Soils in a young landscape on the coast of southern Finland. Agricultural and Food Science in Finland 9: 291-302. https://doi.org/10.23986/afsci.5670

Monti, A., Amaducci, M.T. \& Venturi, G. 2005. Growth response and leaf gas exchange and fructans accumulation of Jerusalem artichoke (Helianthus tuberosus L.) as affected by different water regimes. European Journal of Agronomy 23: 136-145. https:// doi.org/10.1016/j.eja.2004.11.001

Negro, M.J., Ballesteros, I., Manzanares, P., Oliva, J.M., Sáez, F. \& Ballesteros, M. 2006. Inulin-containing biomass for ethanol production: carbohydrate extraction and ethanol fermentation. Applied Biochemistry and Biotechnology 129-132: 922-932. https:// doi.org/10.1385/ABAB:132:1:922

Obernberger, I. \& Thek, G. 2004. Physical characterisation and chemical composition of densified biomass fuels with regard to their combustion behaviour. Biomass and Bioenergy 27: 653-669. https://doi.org/10.1016/j.biombioe.2003.07.006

Philp, J.C., Ritchie, R.J. \& Allan, J.E.M. 2013. Biobased chemicals: the convergence of green chemistry with industrial biotechnology. Trends in Biotechnology 31: 219-222. https://doi.org/10.1016/j.tibtech.2012.12.007 
Rodrigues, M.A., Coutinho, J., Martins, F. \& Arrobas M. 2005. Quantitative side dress nitrogen recommendations for potatoes based upon crop nutritional indices. European Journal of Agronomy 23: 79-88. https://doi.org/10.1016/j.eja.2004.10.001

Rodrigues, M.A., Sousa, L., Cabanas, J.E. \& Arrobas, M. 2007. Tuber yield and leaf mineral composition of Jerusalem artichoke (Helianthus tuberosus L.) grown under different cropping practices. Spanish Journal of Agricultural Research 5: 545-553. https:// doi.org/10.5424/sjar/2007054-275

Schittenhelm, S. 1999. Agronomic performance of root chicory, Jerusalem artichoke, and sugarbeet in stress and non-stress environments. Crop Science 39: 1815-1823. https://doi.org/10.2135/cropsci1999.3961815x

Seleiman, M.F., Santanen, A., Jaakkola, S., Ekholm, P., Hartikainen, H., Stoddard, F.L. \& Mäkelä, P.S.A. 2013. Biomass yield and quality of bioenergy crops grown with synthetic and organic fertilizers. Biomass and Bioenergy 59: 477-485. https://doi.org/10.1016/j. biombioe.2013.07.021

Slimestad, R., Seljaasen, R., Meijer, K. \& Skar, S.L. 2010. Norwegian-grown Jerusalem artichoke (Helianthus tuberosus L.): morphology and content of sugars and fructo-oligosaccharides in stems and tubers. Journal of the Science of Food and Agriculture 90: 956-964.

Stoddard, F.L. 2007. The role of legumes in bioenergy production. NJF Seminar 405, Production and utilization of crops for energy. Vilnius, Lithuania, 25.-26.9.2007.

Tammeorg, P., Simojoki, A., Mäkelä, P., Stoddard, F.L., Alakukku, L. \& Helenius, J. 2014. Biochar application to a fertile sandy clay loam in boreal conditions: effects on soil properties and yield formation of wheat, turnip rape and faba bean. Plant and Soil. 374 : 89-107. https://doi.org/10.1007/s11104-013-1851-5

Tencl, J. \& Sladky, V. 2001. Effect of harvest time on moisture content and heating value of biofuels. Research in Agricultural Engineering 47: 1-5.

Tuck, G., Glendining, M.J., Smith, P., House, J.I. \& Wattenbach, M. 2006. The potential distribution of bioenergy crops in Europe under present and future climate. Biomass and Bioenergy 30: 183-197. https://doi.org/10.1016/j.biombioe.2005.11.019

Yang, L., He, Q.S., Corscadden, K. \& Udenigwe, C.C. 2015. The prospects of Jerusalem artichoke in functional food ingredients and bioenergy production. Biotechnology Report 5:77-88. https://doi.org/10.1016/j.btre.2014.12.004 